\title{
Trichothiodystrophy 4, Nonphotosensitive
}

National Cancer Institute

\section{Source}

National Cancer Institute. Trichothiodystrophy 4, Nonphotosensitive. NCI Thesaurus. Code C146899.

A subtype of trichothiodystrophy caused by mutation(s) in the MPLKIP gene, encoding M-phase-specific PLK1-interacting protein. 